\title{
Keanekaragaman Plankton di Sungai Komering Desa Serdang Menang Kecamatan Sirah Pulau Padang Kabupaten OKI
}

\author{
Muhammad Taufan Febrianto ${ }^{1}$, Indah Anggraini Yusanti ${ }^{2 *}$, Syaeful Anwar ${ }^{3}$ \\ *e-mail : indahayusanti@gmail.com \\ ${ }^{1,2}$ Program Studi Ilmu Perikanan Fakultas Perikanan Universitas PGRI Palembang \\ ${ }^{3}$ Program Studi Budidaya Ikan Fakultas Perikanan Universitas PGRI Palembang
}

\begin{abstract}
The purpose of this study was to determine the diversity index of plankton in the Komering River Serdang Menang Village, Sirah Pulau Padang District, Ogan Komering Ilir Regency. This research was conducted in March until April 2018 in the Komering River in Serdang Menang Village, Sirah Pulau Padang District, Ogan Komering Ilir Regency. Sampling method uses Purposive Random Sampling which consists of 3 observation stations, namely: station 1 sand mining area, station 2 floating net cage fish farming area and station 3 densely populated area. The results of the study found that the composition of plankton in the Komering River in Serdang Menang Village, Subdistrict of Sirah Pulau Padang in Ogan Komering Ilir Regency consisted of 3 phytoplankton classes, namely Bacillariophyceae, Chlorophyceae and Cyanophyceae, while the zooplankton class consisted of 4 classes, namely Mastigophora, Monogononta, Crustacea and Ciliophora. The highest diversity index for phytoplankton was obtained at stasion 1 in the sand mining area with a value of 1,39 , which indicates that the level of diversity is included in the mediun category. At zooplankton the highest diversity indev was found at station 3 with a value of 0,33 which indicates that the level of diversity is included in the low category. While the highest dominace index in phytoplankton was found in station 3 in densely populated areas with a value of 0,43 while in zooplankton it was found in stasion 1 in the sand mining area with a value of 0,00563 , both value indicate that there is no genus of plankton that dominates in the area.
\end{abstract}

Keywords: Plankton, Diversity, Komering River, Serdang Menang Village

\begin{abstract}
ABSTRAK
Tujuan penelitian ini adalah untuk mengetahui indeks keanekaragaman plankton di Sungai Komering Desa Serdang Menang Kecamatan Sirah Pulau Padang Kabupaten Ogan Komering Ilir. Penelitian dilaksanakan pada bulan Maret sampai April 2018 di Sungai Komering Desa Serdang Menang Kecamatan Sirah Pulau Padang Kabupaten Ogan Komering Ilir. Metode Sampling menggunakan Purposive Random Sampling yang terdiri dari 3 stasiun pengamatan yaitu stasiun 1 daerah pertambangan pasir, stasiun 2 daerah budidaya ikan keramba jaring apung dan stasiun 3 daerah padat penduduk. Hasil penelitian ditemukan bahwa komposisi plankton di Sungai Komering Desa Serdang Menang Kecamatan Sirah Pulau Padang Kabupaten Ogan Komering Ilir terdiri dari 3 kelas fitoplankton, yaitu Bacillariophyceae, Chlorophyceae dan Cyanophyceae, sedangkan kelas zooplankton terdiri dari 4 kelas, yaitu Mastigophora, Monogononta, Crustacea dan Ciliophora. Indeks keanekaragaman tertinggi pada fitoplankton diperoleh pada stasiun 1 daerah pertambangan pasir dengan nilai 1,39 yang mengindikasikan bahwa tingkat keanekaragaman termasuk dalam kategori sedang. Pada zooplankton indeks keanekaragaman tertinggi ditemukan pada stasiun 3 dengan nilai 0,33 yang mengindikasikan bahwa tingkat keanekaragaman termasuk
\end{abstract}


dalam kategori rendah. Sedangkan indeks dominansi tertinggi pada fitoplakton ditemukan pada stasiun 3 daerah padat penduduk dengan nilai 0,43 sedangkan pada zooplankton ditemukan pada stasiun 1 daerah pertambangan pasir dengan nilai 0.00563 , nilai keduanya mengindikasikan bahwa tidak ada genus plankton yang mendominasi di daerah tersebut.

Kata Kunci: Plankton, Keanekaragaman, Sungai Komering, Desa Serdang Menang

\section{PENDAHULUAN}

Sungai Musi merupakan sungai yang menjadi muara bagi puluhan sungai besar dan kecil di Bengkulu maupun Sumatera Selatan. Sungai Musi memiliki panjang sekitar $700 \mathrm{~km}$ dengan luas daerah aliran sungai (DAS) Musi sekitar 2,5 juta ha atau sekitar $20 \%$ dari seluruh luas perairan sungai dan lebak yang memiliki total luas sebesar 12,5 juta ha (Husnah dan Wiadnyana, 2010 dalam Yuli et al, 2017). Salah satu anak Sungai Musi adalah Sungai Komering yang memiliki panjang aliran sekitar 252,63 $\mathrm{km}$ dengan DAS sekitar 9,918 ha dan debit air sekitar 195,1 $\mathrm{m}^{3} / \mathrm{dtk}$. Sungai Komering mengalir mulai dari Kecamatan Tanjung Lubuk, Kecamatan Pedamaran, Kota Kayuagung, Kecamatan Sirah Pulau Padang, Kecamatan Jejawi dan bermuara di Sungai Musi Palembang (BPS OKI, 2015 dalam Haris, 2019)

Berdasarkan hasil survei dan informasi dari masyarakat sekitar, diketahui bahwa sebagian besar aktifitas masyarakat sekitar aliran Sungai Komering di Desa Serdang Menang memanfaatkan air sungai untuk kegiatan rumah tangga dan kegiatan lainnya, seperti perikanan, penambangan pasir dan pertanian. Aktifitas masyarakat di Sungai Komering tersebut menyebabkan perubahan lingkungan perairan. Soylu dan Gonulol (2003) dalam Rashidy, et al. (2013) menyatakan bahwa lingkungan perairan terdiri dari komponen biotik dan abiotik yang saling berinteraksi melalui aliran energi dan daur hara (nutrien), apabila interaksi keduanya terganggu akanmenyebabkan terjadinya perubahan atau gangguan pada ekosistem perairan sehingga menjadi tidak seimbang.

Perubahan ekosistem perairan akan mempengaruhi keberadaan plankton. Menurut Sachlan (1982), plankton merupakan organisme yang berukuran kecil yang hidup terombang-ambing oleh arus perairan.Keanekaragaman plankton pada suatu perairan dapat dipakai sebagai salah satu indikator biologi dalam menentukan perubahan kondisi perairan tersebut. Untuk itu, perlu dilakukan kajian tentang keanekaragaman plankton di Sungai Komering Desa Serdang Menang Kecamatan Sirah Pulau Padang Kabupaten Ogan Komering Ilir. Hasil penelitian diharapkan dapat dipakai sebagai data awal untuk penilaian terkait kualitas air sungai komering yang ada di Kabupaten OKI.

\section{BAHAN DAN METODE}

\section{a. Lokasi dan Waktu}

Penelitian ini dilaksanakan pada bulan Maret 2018 sampai bulan April 2018 di Sungai Komering Desa Serdang Menang, Kecamatan Sirah Pulau Padang, Kabupaten Ogan Komering Ilir (OKI), Sumatera Selatan.

\section{b. Alat dan Bahan}

Alat yang di pergunakan pada penelitian ini adalah : Sedgwick rafter / cover glass, botol film, kertas label, mikroskop, plankton net no 25 , ember plastik, secchi disk, thermometer, DO meter, $\mathrm{pH}$ meter, kamera, pipet tetes, alat tulis, gelas ukur. Sedangkan bahan yang digunakan adalah air sampel yang diambil dari Sungai Komering dan Lugol. 


\section{c. Metode Penelitian}

Metode penelitian ini menggunakan metode deskriptif mengenai keanekaragaman plankton di Sungai Komering Desa Serdang Menang Kabupaten Ogan Komering Ilir. Pengambilan sampel plankton menggunakan metode purposive random sampling.

\section{d. Prosedur Penelitian}

\section{Lokasi Pengambilan Sampel Plankton}

Pengambilan sampel plankton dilakukan di 3 (tiga) titik stasiun pengambilan sampel di Sungai Komering Desa Serdang menang Kabupaten Ogan Kemering Ilir, yaitu :

- Stasiun 1 merupakan area penambangan pasir dengan titik koordinat stasiun yaitu $3^{\circ} 18^{\prime} 59.45^{\prime \prime} \mathrm{S}$ dan 10452'53.49"E memiliki jarak $450 \mathrm{~m}$ ke stasiun 2. Vegetasi di sekitar lokasi terdapat banyak enceng gondok dan rumput ilalang.

- Stasiun 2 merupakan area budidaya ikan keramba jaring apung dengan titik koordinat stasiun yaitu $3^{\circ} 19^{\prime} 6.90^{\prime \prime} \mathrm{S}$ dan 10452'55.30"E memiliki jarak antara stasiun 2 ke stasiun 3 sejauh $450 \mathrm{~m}$. Vegetasi di sekitar lokasi terdapat banyak enceng gondok dan rumput ilalang.

Stasiun 3 merupakan area padat penduduk dengan titik koordinat stasiun ini yaitu $3^{\circ} 19^{\prime} 15.80 " \mathrm{~S}$ dan $104^{\circ} 53^{\prime} 8.00^{\prime \prime E}$ memiliki jarak antara stasiun 3 ke stasiun 1 sejauh $950 \mathrm{~m}$. Vegetasi di sekitar lokasi banyak di temukan enceng gondok dan rumput ilalang.

\section{Pengambilan Sampel Plankton}

Langkah-langkah pengambilan sampel yaitu siapkan jaring plankton, ambil sampel air menggunakan ember dengan volume 5 liter, setelah itu sampel air di masukan ke dalam jaring plankton net, dilakukan pengulangan sebanyak 10 kali sampai volume sampel air mencapai
50 liter. Air yang tertampung di ujung jaring plankton dipindahkan ke botol sampel sebanyak $200 \mathrm{ml}$, kemudian tetesi sampel sebanyak $2 \mathrm{ml}$ dengan larutan lugol, kocok botol sampel hingga homogen dan air sampel terlihat berwarna kecoklatan. Kemudian tutup rapat botol sampel, beri label stasiun, waktu dan tempat.

\section{Identifikasi Plankton}

Identifikasi dan analisis plankton dilakukan di Laboratorium Hidrobiologi Balai Riset Perikanan Perairan Umum dan Penyuluhan Perikanan Palembang Jakabaring

\section{e. Analisa Data \\ Indeks Keanekaragaman}

Analisis indeks keanekaragaman digunakan untuk mengetahui keanekaragaman jenis organisme akuatik. Persamaan yang digunakan untuk menghitung indeks ini mengacu pada persamaan Shanon - Wiener (Odum, 1993 dalam Yusanti, 2018)

$$
\mathrm{H}^{\prime}=-\sum_{z=1}^{z} \mathrm{Pi} . \mathrm{Ln} \mathrm{Pi}
$$

Keterangan :

$\mathrm{H}^{\prime}$ = Indeks Keanekaragaman

$\mathrm{S}=$ Jumlah Spesies

$\mathrm{Pi}=n \mathrm{ni} / \mathrm{N}$

$\mathrm{Ni}=$ total jumlah individu spesies ke $\mathrm{i}$

$\mathrm{N}=$ jumlah total individu dalam komunitas

Kriteria indeks keanekaragaman dibagi dalam 3 kategori yaitu :

$\mathrm{H}^{\prime}<1=$ keanekaragaman rendah

$\mathrm{H}^{\prime}<3=$ keanekaragaman sedang

$\mathrm{H}^{\prime}>3$ = keanekaragaman tinggi

\section{Indeks Dominansi}

Indek dominasi digunakan untuk mengetahui adanya pendominasian jenis tertentu di perairan dengan menggunakan persamaan rumus Simpson (Odum 1993). 


$$
\mathrm{D}=\sum(\mathrm{pi})^{2}=\sum\left(\frac{\mathrm{mi}}{N}\right)^{2}
$$

Keterangan :

$\mathrm{D}=$ indeks dominasi

$\mathrm{Ni}=$ total jumlah individu spesies ke $\mathrm{i}$ (ind/l)

$\mathrm{N}=$ jumlah total plankton tiap titik pengambilan sampel (ind/l)

$\mathrm{Pi}=\mathrm{ni} / \mathrm{N}$

\section{HASIL DAN PEMBAHASAN}

\section{Komposisi Plankton}

Hasil identifikasi sampel plankton di Sungai Komering Desa Serdang Menang Kabupaten Ogan Komering Ilir diperoleh komposisi genus plankton yang terdiri dari 3 kelas fitoplankton yaitu Bacillariophyceae sebanyak 13 (tiga belas) genus, yaitu Achnanthes, Coconeis, Coscinodiscus, Cymbella, Diatoma, Epithemia, Fragilaria, Melosira, Navicula, Nitszthia, Pinularia, Surirella dan Synendra. Kelas Chlorophyceae sebanyak 14 (empat belas) genus, yaitu Ankistrodesmus, Ankistrodesmus, Closterium, Cosmarium, Cyclotella, Gleocystis, Gonatozygon, Mougeotia, Oedogonium, Pediastrum, Pleurotaenium, Scenedesmus, Staurastrum, Stigeoclonium farctum dan Tetraedron. Untuk kelas Cyanophyceae sebanyak 7 (tujuh) genus, yaitu Aphanizomenon, Gomphospaheria, Hydrodiction, Merismopedia, Oscilllatoria, Phormidium dan Stigeonema.

Sedangkan zooplankton terdiri dari 4 kelas yaitu Mastigophora sebanyak 5 (lima) genus, yaitu Arcella, Difflugia, Euglena, Phacus dan Trachelomonas. Kelas Monogononta sebanyak 7 (tujuh) genus, yaitu Anureopsis, Asplanchna, Keratella, Lecane, Monostyla, Notholca,
Trichocerca. Kelas Crustacea sebanyak 1 (satu) genus, yaitu Nauplius dan Ciliophora sebanyak 1 (satu) genus yaitu Stentor.

Nilai indeks keanekaragaman plankton yang terdiri dari fitoplankton dan zooplankton pada setiap stasiun pengambilan sampel di Sungai Komering Desa Serdang Menang Kabupaten Ogan Komering Ilir selengkapnya dapat dilihat pada Tabell.

\section{Keanekaragaman Plankton}

Dari Tabel 1 tersebut didapatkan nilai rata-rata indeks keanekaragaman fitoplankton tertinggi diperoleh pada stasiun larea penambangan pasir adalah 1,39, diikuti oleh stasiun 2 area budidaya ikan keramba jaring apung dengan nilai sebesar 1,29. Berdasarkan indeks Shannon-Wienner nilai tersebut menunjukkan bahwa keanekaragaman fitoplankton termasuk dalam kategori sedang, dimana nilai keanekaragaman $1<$ $\mathrm{H}^{\prime}<3$ mengindikasikan bahwa keanekaragaman sedang, penyebaran sedang, produktifitas cukup, kondisi ekosistem cukup seimbang, dan tekanan ekologis sedang. Pada stasiun 1 area penambangan pasir dan stasiun 2 area budidaya ikan keramba jaring apung memiliki nilai rata-rata keanekaragaman berada pada level sedang, sehingga dapat diartikan bahwa fitoplankton yang ada pada ke 2 (dua) stasiun ini dalam kondisi baik. Menurut pendapat Odum (1998) dalam Alamanda (2012), tingginya nilai indeks keanekaragaman menunjukkan bahwa areapada stasiun 1 dan stasiun 2 tersebut sangat cocok untuk pertumbuhan fitoplankton. 
Tabel 1. Indeks Rata-Rata Keanekaragaman Plankton (H') di Sungai Komering Desa Serdang Menang Kabupaten Ogan Komering Ilir.

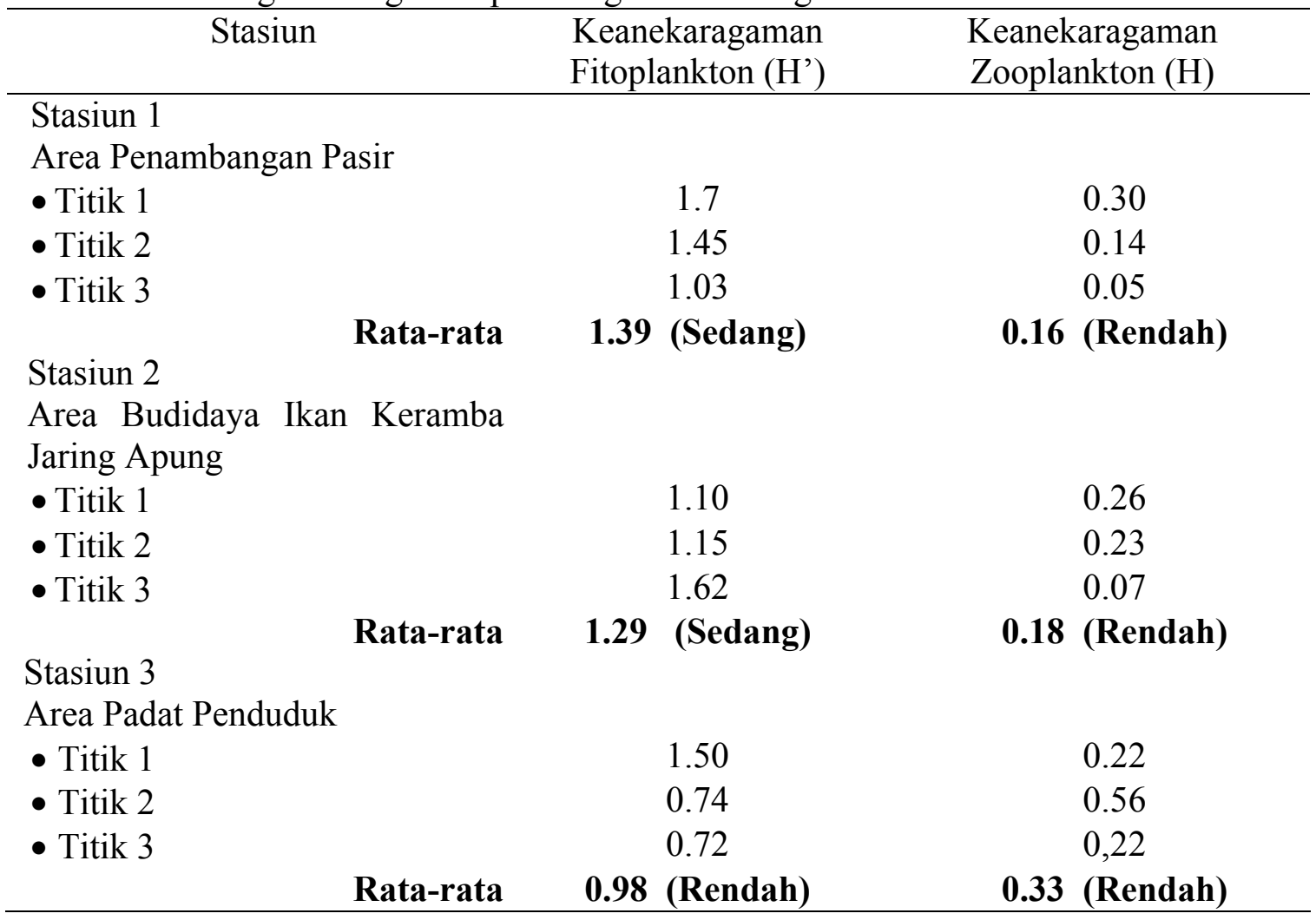

Pada stasiun 3 area padat penduduk, nilai rata-rata indeks keanekaragaman adalah 0,98 . Berdasarkan indeks Shannon-Wienner nilai tersebut menunjukan bahwa keanekaragaman fitoplankton di kategorikan rendah. Nilai keanekaragaman $\mathrm{H}^{\prime}<1$ mengindikasikan bahwa keanekaragaman rendah, tidak stabil, miskin, produktivitas sangat rendah sebagai indikasi adanya tekanan yang berat dan ekosistem tidak stabil. Rendahnya nilai keanekaragaman fitoplankton pada stasiun 3 area padat penduduk, diduga karena fitoplankton tidak dapat beradaptasi dengan baik, hal ini dikarenakan pada stasiun tersebut,berdasarkan pengamatan di lapangan merupakan daerah padat rumahpenduduk yang menyebabkan tingginya aktifitas penduduk. Sinaga (2009) dalam Luthfia (2013) mengatakan bahwa penambahan bahan organik maupun anorganik berupa limbah dalam perairan selain mengubah susunan kimia air, juga dapat mempengaruhi sifat-sifat biologi dari perairan tersebut. Luthfia (2013) dalam Yusanti (2017) juga menambahkan bahwa adanya pencemaran dapat menyebabkan keanekaragaman spesies menurun.

Dari Tabel 1 diatas juga diperoleh nilai indeks keanekaragaman zooplankton pada setiap stasiun pengambilan sampel di Sungai Komering Desa Serdang Menang Kecamatan Sirah Pulau Padang Kabupaten Ogan Komering Ilir. Pada stasiun 1 area penambangan pasir diperoleh nilai rata-rata 0,16 , stasiun 2 area budidaya ikan keramba jaring apung didapatkan nilai rata-rata 0,18 dan stasiun 3 area padat penduduk memiliki nilai rata-rata 0,33. Berdasarkan indeks keanekaragaman Shannon-Wiener, nilai tersebut menunjukkan bahwa keanekaragaman zooplankton $\mathrm{H}^{\prime}<1$ 
yang mengindikasikan tingkat keanekaragaman yang termasuk dalam kategori rendah, tidak stabil, miskin, produktifitas sangat rendah sebagai indikasi adanya tekanan yang berat dan ekosistem tidak stabil.

Rendahnya nilai keanekaragaman zooplankton diduga karena zooplankton tidak mampu beradaptasi dengan kondisi lingkungannya. Selain itu, dalam sistem rantai makanan di perairan, zooplankton merupakan sumber makanan bagi organisme lainnya, misalnya ikan. Dugaan lain adanya kemungkinan timbulnya sifat kanibalisme diantara zooplankton akibat dari sedikitnya ketersediaan fitoplakton sebagai sumber makanannya. Adanya sifat kanibal pada zooplankton ini diperkuat oleh penyataan Ningrum (2015), yang menyatakan bahwa kanibal pada zooplankton disebabkan tidak tercukupi kebutuhan makanannya sehingga semakin memperbesar kemungkinan menipisnya jumlah zooplankton yang ditemukan.

\section{Indeks Dominansi}

Berdasarkan hasil identifikasi plankton di Sungai Komering Desa Serdang Menang Kabupaten Ogan Komering Ilir diperoleh nilai indeks dominansi plankton yang tersaji pada Tabel 2 berikut ini.

Tabel 2. Indeks Dominansi Plankton (D) di Sungai Komering Kecamatan Sirah Pulau Padang Desa Serdang Menang Kabupaten Ogan Komering Ilir

\begin{tabular}{|c|c|c|}
\hline Stasiun & $\begin{array}{l}\text { Dominansi (D) } \\
\text { Fitoplankton } \\
\end{array}$ & $\begin{array}{c}\text { Dominansi (D) } \\
\text { Zooplankton } \\
\end{array}$ \\
\hline \multicolumn{3}{|l|}{ Stasiun 1} \\
\hline \multicolumn{3}{|l|}{ Area Penambangan Pasir } \\
\hline - Titik 1 & 0.17 & 0.016 \\
\hline - Titik 2 & 0.28 & 0.0004 \\
\hline - Titik 3 & 0.58 & 0.0005 \\
\hline Rata-rata & 0.34 & 0.00563 \\
\hline $\begin{array}{l}\text { Stasiun } 2 \\
\text { Area Budidaya Ikan }\end{array}$ & & \\
\hline $\begin{array}{l}\text { Keramba Jaring Apung } \\
\text { - Titik } 1 \\
\text { - Titik } 2 \\
\text { - Titik } 3\end{array}$ & $\begin{array}{l}0.38 \\
0.40 \\
0.24\end{array}$ & $\begin{array}{c}0 \\
0,001 \\
0.0001\end{array}$ \\
\hline Rata-rata & 0.34 & 0.0010 \\
\hline $\begin{array}{l}\text { Stasiun } 3 \\
\text { Area Padat Penduduk }\end{array}$ & & \\
\hline - $\quad$ Titik 1 & 0.25 & 0.001 \\
\hline - $\quad$ Titik 2 & 0.44 & 0 \\
\hline - $\quad$ Titik 3 & 0,61 & 0.003 \\
\hline Rata-rata & 0.43 & 0.0013 \\
\hline
\end{tabular}

\begin{tabular}{ll}
\hline Berdasarkan Tabel 2 diatas & dan area budidaya ikan keramba jaring \\
terlihat bahwa indeks dominansi & apung sebesar 0,34. Untuk indeks \\
fitoplankton yang paling tinggi terdapat & dominansi zooplankton, nilai tertinggi \\
pada stasiun 3 area padat penduduk & ditemukan stasiun 1 area penambangan \\
dengan nilai rata-rata indeks dominansi & pasir sebesar 0,00563 , sedangkan \\
0,43 , sedangkan nilai rata-rata indeks & terendah pada stasiun 2 area budidaya \\
dominansi terendah di dapat pada stasiun & ikan keramba jaring apung dan 3 area \\
1 dan 2, yaitu area penambangan pasir & padat penduduk, yaitu sebesar 0,0013 dan
\end{tabular}


0,0010. Nilai tersebut menunjukkan bahwa pada ke 3 (tiga) stasiun tersebut tidak terdapat genus yang mendominansi. Pernyataan tersebut sesuai dengan pendapat Magurran (1998) dalam Dewiyanti, $d k k$ (2014) yang menyatakan bahwa apabila nilai indeks dominansi mendekati nilai 1 (satu) berarti dalam struktur komunitas tersebut terdapat genus yang mendominansi, sebaliknya apabila mendekati nilai 0 (nol) berarti dalam struktur komunitas tersebut tidak terdapat genus yang secara ektrim mendominansi.Hal tersebut menunjukan bahwa kondisi struktur komunitas dalam keadaan labil dan terjadi tekanan ekologis.

Menurut Odum (1993), hilangnya suatu jenis yang dominan akan menimbulkan perubahan - perubahan penting tidak hanya dalam komunitas biotiknya sendiri tetapijuga dalam lingkungan fisiknya. Adanya dominansi suatu jenis plankton dapat diindikasikan perairan tersebut sudah tercemar atau kurang baik, sehingga hanya jenis tertentu saja yang bisa beradaptasi pada kondisi perairan tersebut.

\section{KESIMPULAN}

Komposisi plankton di Sungai
Komering Desa Serdang Menang
Kecamatan Sirah Pulau Padang
Kabupaten Ogan Komering Ilir terdiri
dari 3 kelas fitoplankton, yaitu
Bacillariophyceae, Chlorophyceae dan
Cyanophyceae, sedangkan kelas
zooplankton terdiri dari 4 kelas, yaitu
Mastigophora, Monogononta, Crustacea
dan Ciliophora. Indeks keanekaragaman
tertinggi pada fitoplankton diperoleh
pada stasiun 1 daerah pertambangan pasir
dengan nilai 1,39 yang mengindikasikan
bahwa tingkat keanekaragaman termasuk
dalam kategori sedang. Pada zooplankton
indeks keanekaragaman tertinggi
ditemukan pada stasiun 3 dengan nilai
0,33 yang mengindikasikan bahwa

tingkat keanekaragaman termasuk dalam kategori rendah. Sedangkan indeks dominansi tertinggi pada fitoplakton ditemukan pada stasiun 3 daerah padat penduduk dengan nilai 0,43 sedangkan pada zooplankton ditemukan pada stasiun 1 daerah pertambangan pasir dengan nilai 0.00563 , nilai keduanya mengindikasikan bahwa tidak ada genus plankton yang mendominasi di daerah tersebut.

\section{DAFTAR PUSTAKA}

Alamanda, S., Wiedarti, S., Triastinurmiatiningsih. 2012. Kualitas Air dan Keanekaragaman Jenis Plankton di Sungai Cisadane. Jawa Barat.

Dewiyanti, G.A.D., Irawan B., Noer M. 2014. Kepadatan dan Keanekaragaman Plankton di Perairan Mangetan Kanal Kabupaten Sidoarjo Provinsi Jawa Timur dari Daerah Hulu, daerah Tengah dan Daerah Hilir Bulan Maret 2014. Jurnal Departemen Biologi, Fakultas Sains dan Teknologi Universitas Erlangga, Surabaya.

Haris, RBK., Yusanti, I.A. 2019. Analisis Kesesuaian Perairan untuk Keramba Jaring Apung di Kecamatan Sirah Pulau Padang Kabupaten Ogan Komering Ilir Provinsi Sumatera Selatan. Jurnal Lahan Suboptimal. Vol. 8(1) hal: 20-30.

Luthfia. 2013. Keanekaragaman Zooplankton di Perairan Sungai Pulau Telo Kecamatan Selat Kabupaten Kapuas. Jurnal WahanaBio. X: 67-93.

Ningrum, A. M., Wijiyono. 2015. Zooplankton sebagai indikator biologi pada ekosistem perairan kolam bioremediasi PSTABATAN. Seminar Nasional XI SDM Teknologi Nuklir. Yogyakarta. Hal. 123-128 
Odum, E.P. 1993. Dasar-dasar Ekologi. Terjemahan: Tjahjono Samingan dan B. Srigando. Edisi Ketiga.Gadjahmada University Press. Yogyakarta. xv+613hlm

Rashidy, E.A., Litaay, M., Salam, M.A., Umar, M. R. 2013. Komposisi dan Kelimpahan Fitoplankton di Perairan Pantai Kelurahan Tekolabbua, Kecamatan Pangkajene, Kabupaten Pangkep, Provinsi Sulawesi Selatan. Jurnal Alam dan Lingkungan. Vol.4(7). Hal : 12-16

Sachlan, M. 1982. Planktonologi.Fakultas Peternakan dan Perikanan. Universitas Diponegoro. Semarang. Yuli, S., Harris, H., Yusanti, I.A. 2017. Tingkat Serangan Ektoparasit Pada Ikan Patin (Pangasius hypopthalmus) Yang Dibudidayakan Dalam Keramba Jaring Apung Di Sungai Musi Palembang. Jurnal Ilmu-ilmu Perikanan dan Budidaya Perairan. Vol 12(2) hal : 50-57.

Yusanti, I.A., Widayatsih, T. 2017. Keanekaragaman Fitoplankton Di Rawa Banjiran Desa Sedang Kecamatan Suak Tapeh Kabupaten Banyuasin. Prosiding Seminar Nasional Lahan Suboptimal. Hal : 412-419.

Yusanti, I.A., Widayatsih, T., Ramadhan. 2018. Keanekaragaman Zooplankton di Rawa Banjiran Kecamatan Suak Tapeh Kabupaten Banyuasin. Jurnal Biota. Vol 1(1) hal: 7-11 